\title{
Influenza vaccination: opinions of health care professionals working in pediatric emergency departments
}

\author{
Luciano Pinto ${ }^{1 *}$ (D), Raffaele Falsaperla ${ }^{2}$, Alberto Villani ${ }^{3}$, Giovanni Corsello ${ }^{4}$, Roberto Del Gado ${ }^{5}$, Adolfo Mazzeo ${ }^{6}$ and \\ Riccardo Lubrano ${ }^{6}$
}

\begin{abstract}
Background: Vaccine coverage of health care professionals against influenza is still low in Italy, as well as in other European countries.

Methods: Between March and May 2018, this study was performed to collect the opinions of Pediatric health care professionals, working in emergency departments, regarding the efficacy and safety of the influenza vaccine. An anonymous online survey was employed to evaluate socio-demographic and professional characteristics, knowledges, beliefs and attitudes.

Results: Five hundred four health care professionals completed the survey: 331 physicians, 140 nurses and 33 other health are professionals. During the $2017-18$ season, $55.8 \%$ of physicians, $19.3 \%$ of nurses and $12.1 \%$ of other health care professionals had vaccinated against the influenza virus. Not vaccinated physicians and nurses with less than 40 years of age were fewer than not vaccinated physicians and nurses with more than 40 years of age. Nurses and other health care professionals were less trustworthy of the influenza vaccination, less aware of the possibility of contracting and transmitting influenza and other vaccine-preventable diseases.

Conclusions: Insufficient adherence to the influenza vaccination in physicians, nurses and other health care professionals is a concern for those assisting high-risk patients, especially in emergency departments. Therefore, it is vital to promote education of health care professionals and students regarding vaccinations. High vaccine coverage should be embedded in the safe hospital paradigm and should become a goal for the hospital's directors.
\end{abstract}

Keywords: Influenza vaccination, Health care professionals, Vaccine coverage, Italy

\section{Background}

Influenza vaccination of health care professionals is the most effective public health strategy to prevent influenza's transmission in hospital [1], reduce the mortality of elderly and high-risk patients [2] and limit absences from work during influenza epidemics [3-5].

Health care professionals, by being in contact with potentially infected patients or materials, can contract influenza and spread the virus to their patients, their families and susceptible colleagues. Health care professionals are at higher risk of contracting influenza

\footnotetext{
* Correspondence: lucianopinto@virgilio.it

${ }^{1}$ Società Italiana di Medicina Emergenza Urgenza Pediatrica, Via Nevio 60, 80122 Napoli, Italy

Full list of author information is available at the end of the article
}

compared to healthy adults not working in health care contexts [6]. During each season, $20 \%$ of health care professionals are estimated to contract influenza [7], often continuing working although infected [8], hence favoring the spread of the virus.

The majority of countries recommends annual influenza vaccination for health care professionals but a large number of professionals do not vaccinate. In European countries vaccine coverage is still low (between 5 and $54.9 \%$, with a median of $25.7 \%$ in $2014-15$ ) [9]. In the United States $78.4 \%$ of health care personnel reported having received an influenza vaccination during the 2017-18 season, but vaccination coverage was highest (94.8\%) among health care personnel working in settings where vaccination was required [10]. 
In Italy data on vaccine coverage of health care professionals is quite limited. In the region Veneto there has been a moderate increase in the last years (from 16.7\% in $2013-14$ to $28.8 \%$ in $2017-18$ ) [11], and several studies have shown equivalent variations also in other regions [12]. Nevertheless, vaccine coverage for influenza is clearly far from the $75 \%$ target established by the European Commission for high-risk groups [12-17].

Such matter is relevant especially in pediatric emergency departments, general pediatric wards and intensive care units. Indeed, since the $2009 \mathrm{H} 1 \mathrm{~N} 1$ influenza pandemic, it is known that health care professionals, especially physicians, have a higher risk of contracting influenza in these contexts [18].

During seasonal influenza epidemics, air and surfaces of emergency departments are contaminated with the influenza virus [19] and the possibility of being infected in the emergency department is 3.4 higher (OR 3.4; IC $95 \%, 1.27-9.1)$ than in the operating room [20].

These considerations encouraged the Italian Society of Pediatric Emergency Medicine (SIMEUP) and the Italian Society of Pediatrics (SIP), to publicize an online survey among Pediatric health care professionals working in the emergency department in order to collect their opinion on vaccines' efficacy and safety, with a specific focus on influenza vaccination.

\section{Methods}

An anonymous online survey composed of 4 sections was developed. In the first section, socio-demographic and professional characteristics of the participants were asked: age range, sex, professional role, department and region of work. In the second section, vaccination status was asked, with specific questions on measles, rubella, mumps, varicella, hepatitis $B$, influenza, meningococcus (B, C, C-A-Y-W) and pneumococcus. In the third section, participants were asked to agree on statements concerning influenza, influenza vaccination and, more widely, vaccinations. In the fourth section, the following items were asked: the existence of training activities on vaccination, the knowledge on the existence of quarantine measures in their hospital for susceptible Health care professionals, their opinion on mandatory vaccinations for Health care professionals and, at the end, an optional evaluation of the survey.

The survey was elaborated on Google Forms and was circulated on the SIMEUP's website to all health care professionals (both members and non-members of the society). The survey was also sent by email to all members of SIMEUP and on the newsletter of SIMEUP, in the period between March and May 2018.

Results were analyzed with descriptive statistics, using absolute frequency with percentages for categorical variables and mean with standard deviation (S.D.) for continuous variables.

Attitudes and beliefs were analyzed with a five-point Likert scale, ruling out participants who had not expressed their opinion and grouping the other participants in two categories, "Strongly disagreeing and Disagreeing" and "Strongly agreeing and Agreeing". Odds Ratio (O.R.) was measured between nurse and physicians.

The Parent Attitudes about Childhood Vaccines (PACV) Short Scale [21, 22] was used to evaluate Vaccine Hesitancy in health care professionals.

Statistical analysis was performed using MedCalc Statistical Software version 16.4.3 (MedCalc Software bvba, Ostend, Belgium; https://www.medcalc.org; 2016).

\section{Results}

Five hundred four Health care professionals completed the survey. Three hundred thirty-one were physicians (among them 103 were residents), 140 were nurses and 33 were health care professionals with other roles ('Other'). Participants worked in disparate geographical areas of Italy (Table 1).

$55.8 \%$ of physicians (185/331), $19.3 \%$ of nurses (27/ 140 ), and $12.1 \%$ of health care professionals with other roles (4/33) had vaccinated against influenza in 2017-18 (Table 2).

Not vaccinated physicians and nurses with less than 40 years of age were fewer than not vaccinated physicians and nurses with more than 40 years of age (Table 3, Fig. 1).

$28.6 \%$ of nurses, $11.5 \%$ of physicians and $27.3 \%$ of other health care professionals deemed the risk of contracting influenza as low (nurses and physicians, O.R. 3,08 ; IC $95 \% 2,05-6,47 ; p<0.0001$ ) whereas $22.1 \%$ of nurses, $7.3 \%$ of physicians and $27.3 \%$ of other health care professionals deemed the risk of transmitting influenza as low (between physicians and nurses O.R. 3,64; IC 95\% $2,05-6,47 ; p<0.0001)$.

$90.9 \%$ of physicians, $75,7 \%$ of nurses and $72.7 \%$ of other health care professionals were not afraid about the influenza vaccination causing 'severe damages'. $26.3 \%$ of physicians and $36.4 \%$ of nurses felt vaccine information to be insufficient. $66.2 \%$ of physicians considered appropriate for the influenza vaccination to be required to work as health care professionals, compared to $42.9 \%$ of nurses (O.R. 0.33, IC 85\% 0.21-0.53) and 36.4\% of other health care professionals (Tables 4 and 5).

$37.9 \%$ of nurses and $14.2 \%$ of physicians deemed the risk of contracting a vaccine-preventable disease as low (O.R. 4.26, IC 95\% 2.63-6.89; $p<0.0001$ ). According to $30.7 \%$ of nurses and $13.0 \%$ of physicians (O.R. 4.03; IC $95 \% 2.44-6.66 ; p<0.0001)$, the risk of transmitting a vaccine-preventable disease was low. $58.6 \%$ of nurses, $66.7 \%$ of other health care professionals and $89.1 \%$ of 
Table 1 Socio-demographic characteristics of the participants

\begin{tabular}{|c|c|c|c|c|c|}
\hline & & Physicians & Nurses & Other Health Care professionals & Total \\
\hline \multicolumn{2}{|l|}{ Number of answers } & 331 & 140 & 33 & 504 \\
\hline \multirow[t]{2}{*}{ Sex } & Males & 122 & 37 & 11 & $170(33.7 \%)$ \\
\hline & Females & 209 & 103 & 22 & $334(66.3 \%)$ \\
\hline \multirow[t]{6}{*}{ Age range } & $20-29$ & 67 & 54 & 14 & $135(27.2)$ \\
\hline & $30-39$ & 105 & 27 & 5 & $137(15.1 \%)$ \\
\hline & $40-49$ & 32 & 36 & 8 & $76(15.1 \%)$ \\
\hline & $50-59$ & 63 & 21 & 5 & $89(17.7 \%)$ \\
\hline & $60-69$ & 58 & 2 & 1 & $61(12.1 \%)$ \\
\hline & $70-79$ & 6 & & & $6(1.2 \%)$ \\
\hline \multirow[t]{3}{*}{ Geographic area } & North & 134 & 47 & 9 & $190(37.7 \%)$ \\
\hline & Center & 79 & 34 & 3 & $116(23.0 \%)$ \\
\hline & South and Islands & 118 & 59 & 21 & $198(39.3 \%)$ \\
\hline
\end{tabular}

physicians were not afraid of side effects caused by vaccines. $19.3 \%$ of nurses and $7.5 \%$ of physicians did not trust information on vaccines. The majority of nurses (64.3\%) and physicians (76.7\%) deemed appropriate for vaccinations to be a required to work as health care professionals; $33.3 \%$ of nurses deemed the number of vaccines administered during one visit as excessive (physicians: 9.4\%) and 21.4\% of nurses preferred natural active immunity to acquired active immunity (physicians: $4.5 \%$ ). $87.3 \%$ of physicians had no doubts about vaccinations, compared to $54.3 \%$ of nurses and $54.5 \%$ of other health care professionals (Tables 6 and 7).

Employing the PACV Short Scale to evaluate vaccine hesitancy, $95.4 \%$ of physicians, $66.4 \%$ of nurses and $63.6 \%$ of other Health care professionals were 'Not hesitant' (score 0-4) (Table 8).

The last question was 'Would you like to express your opinion on this topic?'. The most mentioned issues were: the need for education on risks and benefits of vaccines because of its absence during training (24 on 101 answers) and the desire of being vaccinated for free at work (12 on 101 answers) without 'any expenses, also time-wise, because vaccines are needed for the safety of patients'.

\section{Discussion}

The data collected confirms that adherence of Italian health care professionals to influenza vaccination is far from recommended levels, as confirmed by other studies performed in Italy.

Analyzing our sample, in 2017-18 only 6 out of 10 physicians, 2 out of 10 nurses and less than 1 out of 10 of other health care professionals had vaccinated against influenza. At the same time, adherence to vaccination was lower in health care professionals with less than 40 years of age. Such data shows there was not enough focus on vaccinal prevention during their training.

Compared to physicians, nurses and other health care professionals were less trustworthy of the influenza vaccine, less aware of the possibility of contracting influenza and other vaccine-preventable diseases and transmitting them to their patients. Also they were unsatisfied of the information received on vaccinations, especially as far as influenza was concerned.

Such matter should worry professionals caring for high-risk patients, both in the pediatric and adult age, especially in emergency departments [23].

Studies performed during the 2009 H1N1 influenza pandemic showed that $50 \%$ of the health care professionals who contracted influenza had actually become infected while working in the hospital, contracting the virus either from patients or other health care professionals [24]. The highest rates of infection were noticed in health care professionals working in adult and pediatric emergency departments [19].

Table 2 Vaccinated Health Care professionals (number of vaccinated/total and \% of vaccinated) in 2017/18 divided by role and geographic area

\begin{tabular}{lllll}
\hline Role & North & Center & South and Islands & Total \\
\hline Others & $2 / 9(22.2 \%)$ & $1 / 3(33.3 \%)$ & $1 / 21(4.8 \%)$ & $33(12.1 \%)$ \\
Nurses & $5 / 47(10.6 \%)$ & $13 / 34(38.2 \%)$ & $9 / 59(15.3 \%)$ & $140(19.3 \%)$ \\
Physicians & $79 / 134(58.9 \%)$ & $52 / 79(65.8 \%)$ & $54 / 118(45.8)$ & $331(55.9 \%)$ \\
Total & $86 / 190(45.3 \%)$ & $66 / 116(56.9 \%)$ & $64 / 198(32.3 \%)$ & $504(42.8 \%)$ \\
\hline
\end{tabular}


Table 3 Adherence to the influenza vaccination in Health Care professionals according to age in 2017/18

\begin{tabular}{|c|c|c|c|c|c|c|c|}
\hline \multicolumn{4}{|l|}{ Physicians } & \multicolumn{4}{|l|}{ Nurses } \\
\hline \multirow[t]{2}{*}{ Age in years } & \multicolumn{2}{|l|}{ Vaccinated } & & \multirow[t]{2}{*}{ Age in years } & \multicolumn{2}{|l|}{ Vaccinated } & \\
\hline & No & Yes & & & No & Yes & \\
\hline $20-39$ & 89 (51.7\%) & $83(48,3 \%)$ & \multirow{2}{*}{$\begin{array}{l}\text { O.R. } 0.52 \\
\text { I.C. } 95 \% 0.34-0.81 \\
P=0.0038\end{array}$} & $20-39$ & 69 (85.2\%) & $12(14.8 \%)$ & \multirow{2}{*}{$\begin{array}{l}\text { O.R. } 0.51 \\
\text { I.C. } 95 \% 0.21-1.1\end{array}$} \\
\hline$>40$ & 57 (35.8\%) & $102(64.2 \%)$ & & $>40$ & $44(74.6 \%)$ & $15(25.4 \%)$ & \\
\hline
\end{tabular}

During the influenza season, and even more during epidemics, there is higher demand of medical care in hospitals [25]. Hospitals become overwhelmed with urgent and complex cases and, especially in pediatrics, also with not urgent patients. This happens either because families cannot access primary care [26], or because they have a broad concept of urgency [27, 28]. When more patients must be assisted, more health care professionals are needed. If health care professionals contract influenza themselves, the system will crumble. Therefore, it is important that health care professionals protect themselves through routine hygienical procedures as well as vaccines $[29,30]$.

The National Vaccine Prevention Plan (PNPV) 201719 highlighted that 'every hospital should actively promote initiatives to increase adherence to vaccines in health care professionals and Health care students during the annual vaccine campaign held in Autumn' [31]. At the same time, the Ministry of Health recommended to administer the influenza vaccine to all health care professionals 'especially those working in departments at high risk of contracting and transmitting influenza, such as emergency departments and intensive care units, etc.' [30].

The influenza vaccine is free for health care professionals because it is part of the Essential Levels of Care (LEA) [32]. Nevertheless, vaccine coverage is still low in physicians and, even more in nurses and other health care professionals [11, 12, 33-37]. Commonly, in a department nurses are more in number than physicians and considering also other health care professionals, it is clear that such low rates of vaccinations cannot be accepted and interventions should be implemented to increase vaccine coverage.

\section{What are the possible strategies?}

To promote a higher adherence, a large quantity of tools have been employed, including memos, posters, fliers, text messages, emails to 'gently push' [38] health care professionals to vaccinate, together with educational activities on vaccines, open access to vaccine centers and vaccinations at the workplace $[39,40]$.

In the 'IRCCS Ospedale San Martino di Genova' the unit of Hygiene offered the influenza vaccine on the spot

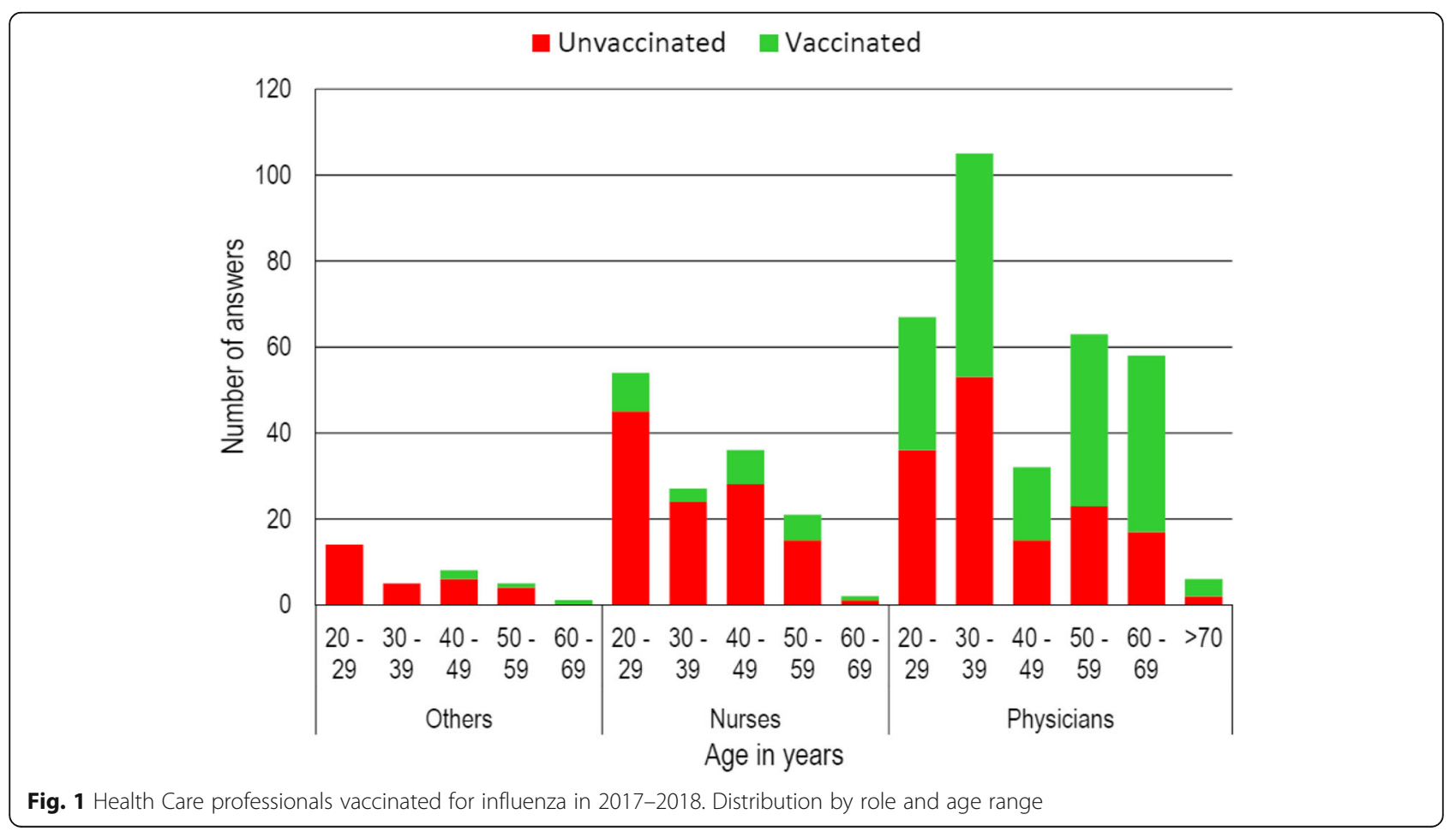


Table $\mathbf{4}$ Levels of agreement on statements regarding the influenza vaccine

\begin{tabular}{|c|c|c|c|c|c|c|c|c|c|}
\hline \multirow[t]{2}{*}{ Statements regarding the influenza vaccine } & \multirow[t]{2}{*}{ Role } & \multicolumn{2}{|c|}{$\begin{array}{l}\text { Not agreeing } \\
(1+2)\end{array}$} & \multicolumn{2}{|c|}{ Uncertain } & \multicolumn{2}{|c|}{$\begin{array}{l}\text { Agreeing } \\
(4+5)\end{array}$} & \multirow[t]{2}{*}{ Total } & \multirow[t]{2}{*}{$\begin{array}{l}\text { Mean } \pm \text { Standard } \\
\text { Deviation (IC 95\%) }\end{array}$} \\
\hline & & $\mathrm{N}^{\circ}$ & $\%$ & $\mathrm{~N}^{\circ}$ & $\%$ & $\mathrm{~N}^{\circ}$ & $\%$ & & \\
\hline \multirow[t]{4}{*}{ I believe that my risk of contracting influenza is low } & Others & 15 & 45.5 & 9 & 27.3 & 9 & 27.3 & 33 & $2.64 \pm 1.39(2.14-3.13$ \\
\hline & Nurses & 64 & 45.7 & 36 & 25.7 & 40 & 28.6 & 140 & $2.75 \pm 1.29(2.53-2.96$ \\
\hline & Physician & 273 & 82.5 & 20 & 6.0 & 38 & 11.5 & 331 & $1.73 \pm 1.13(1.61-1.86$ \\
\hline & Total & 352 & 69.8 & 65 & 12.9 & 87 & 17.3 & 504 & $2.08 \pm 1.28(1.96-2.19$ \\
\hline \multirow{4}{*}{$\begin{array}{l}\text { I believe that the risk of transmitting influenza to one } \\
\text { of my patients is low }\end{array}$} & Others & 16 & 48.5 & 8 & 24.2 & 9 & 27.3 & 33 & $2.67 \pm 1.41(2.17-3.17)$ \\
\hline & Nurses & 81 & 57.9 & 28 & 20.0 & 31 & 22.1 & 140 & $2.45 \pm 1.27(2.24-2.66)$ \\
\hline & Physicians & 287 & 86.7 & 20 & 6.0 & 24 & 7.3 & 331 & $1.64 \pm 0.99(1.53-1.74$ \\
\hline & Total & 384 & 76.2 & 56 & 11.1 & 64 & 12.7 & 504 & $1.93 \pm 1.17(1.83-2.03$ \\
\hline \multirow{4}{*}{$\begin{array}{l}\text { I am afraid of 'severe damages' caused by the influenza } \\
\text { vaccination }\end{array}$} & Others & 24 & 72.7 & 7 & 21.2 & 2 & 6.1 & 33 & $1.79 \pm 0.99(1.44-2.14$ \\
\hline & Nurses & 106 & 75.7 & 16 & 11.4 & 18 & 12.9 & 140 & $1.91 \pm 1.22(1.70-2.11)$ \\
\hline & Physicians & 301 & 90.9 & 9 & 2.7 & 21 & 6.3 & 331 & $1.43 \pm 0.96(1.27-1.59$ \\
\hline & Total & 431 & 85.5 & 32 & 6.3 & 41 & 8.1 & 504 & $1.59 \pm 1.06(1.49-1.68$ \\
\hline \multirow[t]{4}{*}{ Information on the influenza vaccine is limited } & Other & 17 & 51.5 & 9 & 27.3 & 7 & 21.2 & 33 & $2.48 \pm 1.15(2.07-2.89$ \\
\hline & Nurses & 57 & 40.7 & 32 & 22.9 & 51 & 36.4 & 140 & $2.65 \pm 1.36(2.70-3.16$ \\
\hline & Physicians & 188 & 56.8 & 56 & 16.9 & 87 & 26.3 & 331 & $2.43 \pm 1.3(2.21-2.57)$ \\
\hline & Total & 262 & 52.0 & 97 & 19.2 & 145 & 28.8 & 504 & $2.57 \pm 1.32(2.46-2.69$ \\
\hline \multirow{4}{*}{$\begin{array}{l}\text { I consider appropriate for the influenza vaccine to be } \\
\text { required to work as Health care professionals }\end{array}$} & Others & 16 & 48.5 & 5 & 15.2 & 12 & 36.4 & 33 & $2.97 \pm 1.51(2.48-3.46$ \\
\hline & Nurses & 48 & 34.3 & 32 & 22.9 & 60 & 42.9 & 140 & $3.11 \pm 1.46(2.87-3.35)$ \\
\hline & Physicians & 58 & 17.5 & 54 & 16.3 & 219 & 66.2 & 331 & $3.85 \pm 1.32(3.63-4.07)$ \\
\hline & Total & 122 & 24.2 & 91 & 18.1 & 291 & 57.7 & 504 & $3.59 \pm 1.42(3.46-3.71)$ \\
\hline
\end{tabular}

to health care professionals of departments at high-risk of infection, collecting their informed consent or dissent and thus increasing vaccine coverage in those departments compared to the others [12]. A similar initiative was carried out in the 'IRCCS Ospedale Pediatrico Bambino Gesù of Rome' during October-December 2017 where a communication campaign was held, promotion activities were organized and access to the influenza vaccination was facilitated: there a was statistically significant increase in vaccine coverage compared to the previous season [38].

In 2013 New York State obligated not vaccinated health care professionals to wear surgical masks when in patients' areas. After this policy was implemented, more health care professionals accepted vaccinations and there was a reduction of health care professionals affected by respiratory diseases and laboratory confirmed influenza [41].

Table 5 Levels of agreement on statements regarding the influenza vaccine between nurses and physicians

\begin{tabular}{|c|c|c|c|c|c|c|}
\hline \multirow[t]{2}{*}{ Statements regarding the influenza vaccine } & \multirow[t]{2}{*}{ Role } & \multicolumn{5}{|c|}{ Agreeing } \\
\hline & & $\mathrm{N}^{\circ}$ & $\%$ & $\mathrm{OR}$ & I.C. $95 \%$ & $p$ \\
\hline \multirow[t]{2}{*}{ I believe that my risk of contracting influenza is low } & Nurses & 40 & 28.57 & 3.08 & $1.87-5.08$ & $P<0.0001$ \\
\hline & Physician & 38 & 11.48 & & & \\
\hline \multirow{2}{*}{$\begin{array}{l}\text { I believe that the risk of transmitting influenza to one } \\
\text { of my patients is low }\end{array}$} & Nurses & 31 & 22.14 & 3.64 & $2.05-6.47$ & $P<0.0001$ \\
\hline & Physicians & 24 & 7.25 & & & \\
\hline \multirow{2}{*}{$\begin{array}{l}\text { I am afraid of 'severe damages' caused by the influenza } \\
\text { vaccination }\end{array}$} & Nurses & 18 & 12.86 & 0.25 & $0.15-041$ & $P=0.0215$ \\
\hline & Physicians & 21 & 6.34 & & & \\
\hline \multirow[t]{2}{*}{ Information on the influenza vaccine is limited } & Nurses & 51 & 36.43 & 1.93 & $1.23-3.05$ & $P=0.0045$ \\
\hline & Physicians & 87 & 26.28 & & & \\
\hline \multirow{2}{*}{$\begin{array}{l}\text { I consider appropriate for the influenza vaccine to be } \\
\text { required to work as Health care professionals }\end{array}$} & Nurses & 60 & 42.86 & 0.33 & $0.21-0.53$ & $P=0.0001$ \\
\hline & Physicians & 219 & 66.16 & & & \\
\hline
\end{tabular}


Table 6 Levels of agreement on statements regarding vaccines

\begin{tabular}{|c|c|c|c|c|c|c|c|c|c|}
\hline \multirow[t]{2}{*}{ Statements regarding vaccines } & \multirow[t]{2}{*}{ Role } & \multicolumn{2}{|c|}{$\begin{array}{l}\text { Not agreeing } \\
(1+2)\end{array}$} & \multicolumn{2}{|c|}{ Uncertain } & \multicolumn{2}{|c|}{$\begin{array}{l}\text { Agreeing } \\
(4+5)\end{array}$} & \multirow[t]{2}{*}{ Total } & \multirow[t]{2}{*}{$\begin{array}{l}\text { Mean }+/ \text { - Standard } \\
\text { Deviation (IC 95\%) }\end{array}$} \\
\hline & & $\mathrm{N}^{\circ}$ & $\%$ & $\mathrm{~N}^{0}$ & $\%$ & $\mathrm{~N}^{\circ}$ & $\%$ & & \\
\hline \multirow{4}{*}{$\begin{array}{l}\text { I believe that my risk of contracting a vaccine- } \\
\text { preventable disease is low }\end{array}$} & Others & 17 & 51.52 & 11 & 33.33 & 5 & 15.15 & 33 & $2.48 \pm 1.20(2.06-2.91)$ \\
\hline & Nurses & 64 & 45.71 & 23 & 16.43 & 53 & 37.86 & 140 & $2.88 \pm 1.41(2.64-3.11)$ \\
\hline & Physicians & 262 & 79.15 & 22 & 6.65 & 47 & 14.20 & 331 & $1.89 \pm 1.20(1.76-2.02)$ \\
\hline & Total & 343 & 68.06 & 56 & 11.11 & 105 & 20.83 & 504 & $2.20 \pm 1.33(2.09-2.32)$ \\
\hline \multirow{4}{*}{$\begin{array}{l}\text { I believe that the risk of transmitting a vaccine- } \\
\text { preventable disease to one of my patients is low }\end{array}$} & Others & 12 & 36.36 & 9 & 27.27 & 12 & 36.36 & 33 & $2.97 \pm 1.33(2.50-3.44)$ \\
\hline & Nurses & 65 & 46.43 & 32 & 22.86 & 43 & 30.71 & 140 & $2.73 \pm 1.30(2.51-2.95)$ \\
\hline & Physicians & 262 & 79.15 & 26 & 7.85 & 43 & 12.99 & 331 & $1.85 \pm 1.14(1.73-1.98)$ \\
\hline & Total & 339 & 67.26 & 67 & 13.29 & 98 & 19.44 & 504 & $2.17 \pm 1.28(2.06-2.28)$ \\
\hline \multirow[t]{4}{*}{ Vaccines' benefits are uncertain } & Others & 19 & 57.58 & 4 & 12.12 & 10 & 30.30 & 33 & $2.64 \pm 1.54(2.09-3.18)$ \\
\hline & Nurses & 89 & 63.57 & 20 & 14.29 & 31 & 22.14 & 140 & $2.31 \pm 1.31(2.09-2.53)$ \\
\hline & Physicians & 293 & 88.52 & 8 & 2.42 & 30 & 9.06 & 331 & $1.52 \pm 1.10(1.40-1.64)$ \\
\hline & Total & 401 & 79.56 & 32 & 6.35 & 71 & 14.09 & 504 & $1.81 \pm 1.28(1.70-1.92)$ \\
\hline \multirow{4}{*}{$\begin{array}{l}\text { Vaccines should be required to work as Health } \\
\text { Care professionals }\end{array}$} & Others & 5 & 15.15 & 3 & 9.09 & 25 & 75.76 & 33 & $3.94 \pm 1.20(3.51-4.36)$ \\
\hline & Nurses & 24 & 17.14 & 26 & 18.57 & 90 & 64.29 & 140 & $3.78 \pm 1.31(3.56-4.00)$ \\
\hline & Physicians & 35 & 10.57 & 42 & 12.69 & 254 & 76.74 & 331 & $4.11 \pm 1.13(3.99-4.23)$ \\
\hline & Total & 64 & 12.70 & 71 & 14.09 & 369 & 73.21 & 504 & $4.01 \pm 1.19(3.90-4.11)$ \\
\hline \multirow[t]{4}{*}{ I am afraid of side effects caused by vaccinations } & Others & 22 & 66.67 & 4 & 12.12 & 7 & 21.21 & 33 & $2.21 \pm 1.36(1.73-2.69)$ \\
\hline & Nurses & 82 & 58.57 & 26 & 18.57 & 32 & 22.86 & 140 & $2.35 \pm 1.36(2.12-2.58)$ \\
\hline & Physicians & 295 & 89.12 & 16 & 4.83 & 20 & 6.04 & 331 & $1.54 \pm 0.93(1.41-1.66)$ \\
\hline & Total & 399 & 79.17 & 46 & 9.13 & 59 & 11.71 & 504 & $1.81 \pm 1.16(1.71-1.91)$ \\
\hline \multirow[t]{4}{*}{ ** I trust the information I received on vaccines } & Others & 8 & 24.24 & 4 & 12.12 & 21 & 63.64 & 33 & $3.61 \pm 1.32(3.14-4.07)$ \\
\hline & Nurses & 27 & 19.29 & 28 & 20.00 & 85 & 60.71 & 140 & $3.61 \pm 1.21(3.82-4.24)$ \\
\hline & Physicians & 25 & 7.55 & 25 & 7.55 & 281 & 84.89 & 331 & $4.24+1.05(4.13-4.35)$ \\
\hline & Total & 60 & 11.90 & 57 & 11.31 & 387 & 76.79 & 504 & $4.02 \pm 1.15(3.92-4.13)$ \\
\hline \multirow{4}{*}{$\begin{array}{l}\text { ** Becoming immune naturally by contracting a } \\
\text { disease is better than becoming immune with } \\
\text { vaccinations }\end{array}$} & Others & 18 & 54.55 & 6 & 18.18 & 9 & 27.27 & 33 & $2.61 \pm 1.34(2.13-3.08)$ \\
\hline & Nurses & 84 & 60.00 & 26 & 18.57 & 30 & 21.43 & 140 & $2.31 \pm 1.35(2.09-2.54)$ \\
\hline & Physicians & 297 & 89.73 & 19 & 5.74 & 15 & 4.53 & 331 & $1.49 \pm 0.89(1.39-1.59)$ \\
\hline & Total & 399 & 79.17 & 51 & 10.12 & 54 & 10.71 & 504 & $1.79 \pm 1.14(1.69-1.89)$ \\
\hline \multirow[t]{4}{*}{ ** Children should receive less vaccines in one visit } & Others & 13 & 39.39 & 9 & 27.27 & 11 & 33.33 & 33 & $2.88 \pm 1.36(2.40-3.36)$ \\
\hline & Nurses & 61 & 43.57 & 32 & 22.86 & 47 & 33.57 & 140 & $2.80 \pm 1.39(2.57-3.03)$ \\
\hline & Physicians & 259 & 78.25 & 41 & 12.39 & 31 & 9.37 & 331 & $1.78 \pm 1.13(1.66-1.90)$ \\
\hline & Total & 333 & 66.07 & 82 & 16.27 & 89 & 17.66 & 504 & $2.14 \pm 1.32(2.02-2.25)$ \\
\hline \multirow[t]{4}{*}{ ** Children receive too many vaccinations } & Other & 21 & 63.64 & 4 & 12.12 & 8 & 24.24 & 33 & $2.33 \pm 1.22(1.90-2.77)$ \\
\hline & Nurses & 94 & 67.14 & 25 & 17.86 & 21 & 15.00 & 140 & $2.11 \pm 1.24(1.91-2.32)$ \\
\hline & Physicians & 304 & 91.84 & 13 & 3.93 & 14 & 4.23 & 331 & $1.42 \pm 0.85(1.33-1.51)$ \\
\hline & Total & 419 & 83.13 & 42 & 8.33 & 43 & 8.53 & 504 & $1.67 \pm 1.06(1.58-1.75)$ \\
\hline \multirow{4}{*}{$\begin{array}{l}\text { ** Overall, do you have doubts/worries regarding } \\
\text { vaccines? } 1 \text { (a lot of doubts) to } 5 \text { (no doubts at all) }\end{array}$} & Others & 11 & 33.33 & 4 & 12.12 & 18 & 54.55 & 33 & $3.30 \pm 1.29(2.85-3.76)$ \\
\hline & Nurses & 40 & 28.57 & 24 & 17.14 & 76 & 54.29 & 140 & $3.37 \pm 1.24(3.16-3.58)$ \\
\hline & Physicians & 29 & 8.76 & 13 & 3.93 & 289 & 87.31 & 331 & $4.25 \pm 0.99(4.14-4.35)$ \\
\hline & Total & 80 & 15.87 & 41 & 8.13 & 383 & 75.99 & 504 & $3.94 \pm 1.17(3.84-4.04)$ \\
\hline
\end{tabular}


Table $\mathbf{7}$ Levels of agreement on statements regarding vaccines between nurses and physicians

\begin{tabular}{|c|c|c|c|c|c|c|}
\hline \multirow[t]{2}{*}{ Statements regarding vaccines } & \multirow[t]{2}{*}{ Role } & \multicolumn{5}{|c|}{ Agree or Strongly Agree } \\
\hline & & $\mathrm{N}^{\circ}$ & $\%$ & $\mathrm{OR}$ & I.C. $95 \%$ & $\mathrm{p}$ \\
\hline \multirow{2}{*}{$\begin{array}{l}\text { I believe that my risk of contracting a vaccine-preventable } \\
\text { disease is low }\end{array}$} & Nurses & 53 & 37.86 & 4.26 & $2.63-6.89$ & $P<0.0001$ \\
\hline & Physicians & 47 & 14.20 & & & \\
\hline \multirow{2}{*}{$\begin{array}{l}\text { I believe that the risk of transmitting a vaccine-preventable } \\
\text { disease to one of my patients is low }\end{array}$} & Nurses & 43 & 30.71 & 4.03 & $2.44-6.66$ & $P<0.0001$ \\
\hline & Physicians & 43 & 12.99 & & & \\
\hline \multirow[t]{2}{*}{ Vaccines' benefits are uncertain } & Nurses & 31 & 22.14 & 3.4 & $1.95-5.9$ & $P<0.0001$ \\
\hline & Physicians & 30 & 9.06 & & & \\
\hline \multirow{2}{*}{$\begin{array}{l}\text { Vaccines should be required to work as Health Care } \\
\text { professionals }\end{array}$} & Nurses & 90 & 64.29 & 0.52 & $0.29-0.92$ & $P=0.0238$ \\
\hline & Physician & 254 & 76.74 & & & \\
\hline \multirow[t]{2}{*}{ I am afraid of side effects caused by vaccinations } & Nurse & 32 & 22.86 & 5.76 & $3.13-10.6$ & $P<0.0001$ \\
\hline & Physicians & 20 & 6.04 & & & \\
\hline \multirow[t]{2}{*}{ I trust the information I received on vaccines } & Nurses & 85 & 60.71 & 0.28 & $0.15-0.51$ & $P<0.0001$ \\
\hline & Physicians & 281 & 84.89 & & & \\
\hline \multirow{2}{*}{$\begin{array}{l}\text { Becoming immune naturally by contracting a disease is better } \\
\text { than becoming immune with vaccinations }\end{array}$} & Nurses & 30 & 21.43 & 7.07 & $3.63-13.75$ & $P<0.0001$ \\
\hline & Physicians & 15 & 4.53 & & & \\
\hline \multirow[t]{2}{*}{ Children should receive less vaccines in one visit } & Nurses & 47 & 33.57 & 6.44 & $3.78-10.96$ & $P<0.0001$ \\
\hline & Physicians & 31 & 9.37 & & & \\
\hline \multirow[t]{2}{*}{ Children receive too many vaccinations } & Nurses & 21 & 15.00 & 4.85 & $2.37-9.91$ & $P<0.0001$ \\
\hline & Physicians & 14 & 4.23 & & & \\
\hline \multirow{2}{*}{$\begin{array}{l}\text { Overall, do you have doubts/worries regarding vaccines? } \\
1 \text { (a lot of doubts) to } 5 \text { (no doubts at all) }\end{array}$} & Nurses & 76 & 54.29 & 0.19 & $0.11-0.33$ & $P<0.0001$ \\
\hline & Physicians & 289 & 87.31 & & & \\
\hline
\end{tabular}

All these procedures are effective in increasing vaccine coverage in health care professionals but only compulsory vaccination allows to reach high levels of vaccinations. The American Academy of Pediatrics has no doubts. Compulsory vaccination for health care professionals is ethical, fair and needed to improve patients' safety. It is a

Table 8 Hesitancy level in Health Care professionals according to the PACV Short Scale (not hesitant: $0-4$ scores)

\begin{tabular}{lllll}
\hline $\begin{array}{l}\text { PAVC Short } \\
\text { Scale }\end{array}$ & \multicolumn{2}{l}{ Role } & Total \\
\cline { 2 - 4 } & Others & Nurses & Physicians & \\
\hline 0 & 7 & 26 & 200 & 233 \\
1 & & 15 & 36 & 51 \\
2 & 4 & 24 & 53 & 81 \\
3 & 4 & 17 & 15 & 36 \\
4 & 6 & 11 & 12 & 29 \\
5 & 3 & 18 & 4 & 25 \\
6 & 5 & 11 & 4 & 20 \\
7 & 1 & 4 & 1 & 6 \\
8 & 2 & 8 & 3 & 13 \\
9 & 1 & 1 & 1 & 3 \\
10 & 33 & 5 & 2 & 7 \\
Total & & 140 & 331 & 504 \\
\hline
\end{tabular}

crucial step forward to reduce hospital-acquired influenza infections and optional vaccination is not sufficient to increase vaccine coverage [42].

Siemieniuk et al. [43] measured that compulsory vaccination determines a reduction of 93\% (IC 95\% 9195\%) of not vaccinated health care professionals, compared to the $74 \%$ reduction reached with vaccine or mask, to the $28-41 \%$ reached with dissent modules, audits and feedback, facilitated access to vaccination, experienced colleagues promoting vaccinations (peer vaccinator), whereas education was associated with the lowest reduction, 11\% (IC 95\% 7-16\%).

It is interesting that $66.2 \%$ of physicians and $42.9 \%$ of nurses who participated in our survey thought that the influenza vaccine should be required to work as health care professionals. Even more professionals agreed on compulsory vaccinations as a whole: $76.8 \%$ of physicians and $64.3 \%$ of nurses.

Is compulsory vaccination a possible strategy in Italy? In June 2018 the region Puglia approved a law [44] imposing to perform the vaccinations included in the PNPV 2017-19 to all workers at risk. Emilia Romagna and Marche, considering the law 'D.lgs. 9 aprile 2008, n. 81' [45] established that vaccinations are required to work in emergency departments, pediatrics and neonatology. 
Although limited, our data highlights the need to promote vaccine education in hospitals and during training to allow students of medical schools, residency programs and other health care degrees, to be properly informed and receptive to accept and promote themselves recommended vaccinations.

Our study has some limits. The research was conducted with an online survey open to all health care professionals, also those who were not members of SIMEUP. Hence, the results obtained should not be considered as representative of the opinion of all SIMEUP members. Moreover, considering the fluctuation of vaccination rates observed in Italy in recent times, our sample can hardly represent the entire population. Nevertheless, the geographical heterogeneity of the participants should guarantee a certain level of consistency about the real situation of health care professionals in Italy.

\section{Conclusions}

In the document 'La Carta di Pisa delle vaccinazioni negli operatori sanitari' [46] endorsed in March, 2017 by several researchers and seven scientific societies, including SIP, the 'absolute importance of vaccinations in health care professionals to achieve vaccine-preventable diseases control' was reiterated.

SIP and SIMEUP invite their members to vaccinate as soon as possible against influenza, to become a vaccine champion and to advocate for all preventive measures required by law to be implemented in emergency departments and other high-risk sectors.

'High vaccine coverage of health care professionals should be embedded in the safe hospital paradigm and/ or should become a goal for hospitals' directors [47].

\section{Abbreviations}

O.R.: Odds Ratio; PACV : Parent Attitudes about Childhood Vaccines; PNPV : National Vaccine Prevention Plan; S.D.: Standard Deviation; SIMEUP : Italian Society of Pediatric Emergency Medicine; SIP : Italian Society of Pediatrics

\section{Acknowledgments}

The authors declare that they have no competing interests

\section{Funding}

The authors declare that they have not had any funding for this research

\section{Availability of data and materials}

After asking for permission to access to prof. Luciano Pinto

lucianopinto@virgilio.it the data are available to the link: https://docs.google. com/spreadsheets/d/1fllsn_jQo4xQbsNa8fuWzYn5yslvj|zHXmSm90jO4Zo/ edit?usp=sharing_eip\&ts=5bfa8e66

\section{Authors' contributions}

PL Substantial contributions to the conception or design of the work; the acquisition, analysis, or interpretation of data for the work, drafting the work or revising it critically for important intellectual content. FR Agreement to be accountable for all aspects of the work in ensuring that questions related to the accuracy or integrity of any part of the work are appropriately investigated and resolved. VA Final approval of the version to be published, the acquisition, of data for the work. CG Final approval of the version to be published, the acquisition, of data for the work. DR Contributions to the acquisition, analysis, or interpretation of data for the work. MA Drafting the work. LR Acquisition, of data for the work. Drafting the work and revising it critically for important intellectual content. All authors read and approved the final manuscript.

Ethics approval and consent to participate

Not applicable

Consent for publication

Not applicable.

\section{Competing interests}

The authors declare that they have no competing interests

\section{Publisher's Note}

Springer Nature remains neutral with regard to jurisdictional claims in published maps and institutional affiliations.

\section{Author details}

'Società Italiana di Medicina Emergenza Urgenza Pediatrica, Via Nevio 60, 80122 Napoli, Italy. ${ }^{2}$ Policlinico-Vittorio Emanuele Università di Catania, UOC di Pediatria e Neonatologia, Catania, Italy. ${ }^{3}$ Ospedale Pediatrico Bambino Gesù, UOC di Pediatria Generale e Malattie Infettive, Roma, Italy. ${ }^{4}$ Università degli Studi di Palermo, Clinica Pediatrica Palermo, Palermo, Italy. ${ }^{5}$ Università degli Studi della Campania "Luigi Vanvitelli", Caserta, Italy. 'Università degli Studi di Roma "La Sapienza" UOC di Pediatria e Neonatologia, Polo di Latina, Roma, Italy.

Received: 30 November 2018 Accepted: 29 March 2019

Published online: 11 April 2019

\section{References}

1. Restivo V, Costantino C, Bono S, et al. Influenza vaccine effectiveness among high-risk groups: a systematic literature review and meta-analysis of casecontrol and cohort studies. Hum. Vaccin. Immunother. 2018;14:724-35. https://doi.org/10.1080/21645515.2017.1321722.

2. Wilde JA, McMillan JA, Serwint J, et al. Effectiveness of influenza vaccine in healthcare professionals. JAMA. 1999;281:908-13. https://doi.org/10.1001/ jama.281.10.908

3. Burls A, Jordan R, Barton P, et al. Vaccinating healthcare workers against influenza to protect the vulnerable - is it a good use of healthcare resources? A systematic review of the evidence and an economic evaluation. Vaccine. 2006;24:4212-21. https://doi.org/10.1016/j.vaccine.2005.12.043.

4. Imai C, Toizumi M, Hall L, et al. A systematic review and meta-analysis of the direct epidemiological and economic effects of seasonal influenza vaccination on healthcare workers. PLoS One. 2018;13:e0198685. https://doi. org/10.1371/journal.pone.0198685.

5. Pereira M, Williams S, Restrick L, London Respiratory Network. Healthcare worker influenza vaccination and sickness absence - an ecological study. Clin Med. 2017;17:484-9. https://doi.org/10.7861/clinmedicine.17-6-484.

6. Kuster SP, Shah PS, Coleman BL, et al. Incidence of influenza in healthy adults and healthcare workers: a systematic review and meta-analysis. PLoS ONE. 2011;6:e26239. https://doi.org/10.1371/journal.pone.0026239.

7. Elder AG, O'Donnell B, McCruden EA, et al. Incidence and recall of influenza in a cohort of Glasgow healthcare workers during the 1993-4 epidemic: results of serum testing and questionnaire. BMJ. 1996;313:1241-2 https:// www.ncbi.nlm.nih.gov/pmc/articles/PMC2352563/.

8. Chiu S, Black CL, Yue X, et al. Working with influenza-like illness: Presenteeism among US health care personnel during the 2014-2015 influenza season. Am J Infect Control. 2017:45:1254-8. https://doi.org/10. 1016/j.ajic.2017.04.008

9. European Centre for Disease Prevention and Control. Seasonal influenza vaccination in Europe. Vaccination recommendations and coverage rates in the EU member states for eight influenza seasons: 2007-2008 to 2014-2015. Stockholm: ECDC; 2017. https://ecdc.europa.eu/sites/portal/files/documents/ influenza-vaccination-2007\%E2\%80\%932008-to-2014\%E2\%80\%932015.pdf

10. Black CL, Yue X, Ball SW, et al. Influenza vaccination coverage among health care personnel - United States, 2017-18 influenza season. MMWR Morb Mortal Wkly Rep. 2018:67:1050-4.

11. Regione Veneto - Influenza - Archivio: Report relativi alla sorveglianza dell'influenza e della campagna vaccinale https://www.regione.veneto.it/ web/sanita/influenza-archivio. 
12. Alicino $C$, ludici $R$, Barberis I, et al. Influenza vaccination among healthcare workers in Italy. Hum Vaccin Immunother. 2015;11:95-100.

13. Esposito S, Bosis S, Pelucchi C, et al. Influenza vaccination among healthcare workers in a multidisciplinary university hospital in Italy. BMC Public Health. 2008;8:422. https://doi.org/10.1186/1471-2458-8-422.

14. Fortunato F, Tafuri S, Cozza V. Et a. low vaccination coverage among italian healthcare workers in 2013: contributing to the voluntary vs. mandatory vaccination debate. Hum. Vaccin. Immunother. 2015;11:133-9. https://doi. org/10.4161/hv.34415.

15. Albano L, Mattuozzo A, Marinelli P, Al e. Knowledge, attitudes and behaviour of hospital health-care workers regarding influenza a/H1N1: a cross sectional survey. BMC Infect Dis. 2014;14:208. https://doi.org/10.1186/ 1471-2334-14-208.

16. Taddei C, Ceccherini V, Niccolai G, et al. Attitude toward immunization and risk perception of measles, rubella, mumps, varicella, and pertussis in health care workers working in 6 hospitals of Florence, Italy 2011. Hum Vaccin Immunother. 2014;10:2612-22. https://doi.org/10.4161/21645515.2014.970879.

17. Leone Roberti Maggiore U, Scala C, Toletone A, et al.. Susceptibility to vaccine-preventable diseases and vaccination adherence among healthcare workers in Italy: a cross-sectional survey at a regional acute-care university hospital and a systematic review. Hum Vaccin Immunother $2017 ; 13: 470$ 476. doi: https://doi.org/10.1080/21645515.2017.1264746.

18. Santos CD, Bristow RB, Vorenkamp JV. Which health care workers were most affected during the spring 2009 H1N1 pandemic? Disaster Med Public Health Prep. 2010;4:47-54. https://doi.org/10.1017/S193578930000241X.

19. Rule AM, Apau O, Ahrenholz SH, et al. Healthcare personnel exposure in an emergency department during influenza season. PLoS ONE. 2018;13: e0203223. https://doi.org/10.1371/journal.pone.0203223.

20. Sandoval C, Barrera A, Ferrés M. Et. al. infection in health personnel with high and low levels of exposure in a hospital setting during the H1N1 2009 influenza a pandemic. PLoS One. 2016;11:e0147271. https://doi.org/10.1371/ journal.pone.0147271.

21. Opel DJ the parent attitudes about childhood vaccines (PACV) survey tool https://www.sabin.org/sites/sabin.org/files/opel_iaim_verfinal_dist_ redacted.pdf

22. Oladejo $\mathrm{O}$, Allen $\mathrm{K}, \mathrm{Amin} \mathrm{A}$, et al. Comparative analysis of the parent attitudes about childhood vaccines (PACV) short scale and the five categories of vaccine acceptance identified by gust et al. Vaccine. 2016;34: 4964-8. https://doi.org/10.1016/j.vaccine.2016.08.046.

23. Jones RM, Xia Y. Annual Burden of Occupationally-Acquired Influenza Infections in Hospitals and Emergency Departments in the United States. Risk Anal. 2018;38:442-53.

24. Wise ME, De Perio M, Halpin J, et al. Transmission of pandemic (H1N1) 2009 influenza to healthcare personnel in the United States. Clin Infect Dis. 2011; 52(Suppl 1):S198-204. https://doi.org/10.1093/cid/ciq038.

25. Glaser CA, Gilliam S, Thompson WW, et al. Medical care capacity for influenza outbreaks, Los Angeles. Emerg Infect Dis. 2002;8:569-74. https:// doi.org/10.3201/eid0806.010370.

26. Fieldston ES, Alpern ER, Nadel FM, et al. A qualitative assessment of reasons for nonurgent visits to the emergency department: parent and health professional opinions. Pediatr Emerg Care. 2012;28:220-5. https://doi.org/10. 1097/PEC.0b013e318248b431.

27. Lega F, Mengoni A. Why non-urgent patients choose emergency over primary care services? Empirical evidence and managerial implications. Health Policy. 2008:88:326-38. https://doi.org/10.1016/j.healthpol.2008.04.005.

28. Pinto $L$, Urbino $A$, Lubrano $R$, et al. Verso un Pronto Soccorso a dimensione di bambino Quaderni ACP, vol. 1; 2017. p. 15-8. https://www.acp.it/wpcontent/uploads/Quaderni-acp-2017_241_15-18.pdf

29. Ministero della Salute - Prevenzione e controllo dell'influenza: raccomandazioni per la stagione 2018-2019 -http://www.trovanorme.salute. gov.it/norme/renderNormsanPdf?anno=2018\&codLeg=64381\&parte= $1 \% 20 \&$ serie $=$ null

30. Peterson K, Novak D, Stradtman L, et al. Hospital respiratory protection practices in 6 U.S. states: a public health evaluation study. Am J Infect Control. 2015;43:63-71. https://doi.org/10.1016/j.ajic.2014.10.008.

31. Ministero della Salute - Piano Nazionale Prevenzione Vaccinale 2017-2019 http://www.salute.gov.it/imgs/C_17_pubblicazioni_2571_allegato.pdf.

32. DPCM 12 gennaio 2017 Definizione e aggiornamento dei livelli essenziali di assistenza di cui all'articolo 1, comma7, el decreto legislativo 30 dicembre 1992, n 502 Allegato 1 Prevenzione collettiva e sanità pubblica http://www. gazzettaufficiale.it/eli/id/2017/03/18/17A02015/sg
33. Hollmeyer HG, Hayden F, Poland G, et al. Influenza vaccination of health care workers in hospitals--a review of studies on attitudes and predictors. Vaccine. 2009;27:3935-44. https://doi.org/10.1016/j.vaccine.2009.03.056.

34. Bellia C, Setbon M, Zylberman P, et al. Healthcare worker compliance with seasonal and pandemic influenza vaccination. Influenza Other Respir Viruses. 2013;(Suppl 2):97-104. https://doi.org/10.1111/irv.12088.

35. Amodio E, Restivo V, Firenze A, et al. Can influenza vaccination coverage among healthcare workers influence the risk of nosocomial influenza-like illness in hospitalized patients? J Hosp Infect. 2014;86:182-7. https://doi.org/ 10.1016/j.jhin.2014.01.005.

36. Durando P, Alicino C, Dini G, et al. Determinants of adherence to seasonal influenza vaccination among healthcare workers from an Italian region: results from a cross-sectional study. BMJ Open. 2016;6:e010779. https://doi. org/10.1136/bmjopen-2015-010779.

37. Gilardi F, Castelli Gattinara G, et al. Seasonal influenza vaccination in health care workers. A pre-post intervention study in an Italian Paediatric hospital. Int J Environ Res Public Health. 2018;15:pii: E841. https:/doi.org/10.3390/ijerph15050841.

38. Thaler R, Sunstein C. Nudge: improving decisions about health, wealth, and happiness. New Haven: Yale University Press; 2008.

39. Gallone MS, Gallone MF, Cappelli MG, et al. Medical students' attitude toward influenza vaccination: results of a survey in the University of Bari (Italy). Hum Vaccin Immunother. 2017;13:1937-41. https://doi.org/10.1080/ 21645515.2017.1320462.

40. Squeri R, Riso R, Facciolà A, et al. Management of two influenza vaccination campaign in health care workers of a university hospital in the South Italy. Ann lg. 2017:29:223-31. https://doi.org/10.7416/ai.2017.2150.

41. Batabyal RA, Zhou JJ, Howell JD, et al. Impact of New York state influenza mandate on influenza-like illness, acute respiratory illness, and confirmed influenza in healthcare personnel. Infect Control Hosp Epidemiol. 2017;38: 1361-3. https://doi.org/10.1017/ice.2017.182.

42. AAP Committee on Infectious Diseases. Influenza immunization for all health care personnel: keep it mandatory. Pediatrics. 2015;136:809-18. https://doi.org/10.1542/peds.2015-2922.

43. Siemieniuk R, Coleman B, Shafiz S, et al. Interventions to increase healthcare worker influenza vaccination: a meta-analysis. Poster ID1713 presented at the IDWeek2014. Advancing science, improving care. October 8-12 2014, Philadelphia, PA, USA. Available at: https://idsa.confex.com/idsa/2014/ webprogram/Paper47456.html

44. Regione Puglia, Legge Regionale 19 giugno 2018, n. 27 Disposizioni per l'esecuzione degli obblighi di vaccinazione degli operatori sanitari BURP 49 n. 82 suppl. del 21-6-2018.

45. D.lgs. 9 aprile 2008, n. 81 Testo unico sulla salute e sicurezza sul lavoro http://lavoro.gov.it/documenti-e-norme/studi-e-statistiche/Documents/ Testo\%20Unico\%20sulla\%20Salute\%20e\%20Sicurezza\%20sul\%20Lavoro/ Testo-Unico-81-08-Edizione-Giugno\%202016.pdf

46. Società Italiana di Pediatria: Rilanciare le vaccinazioni tra gli operatori sanitari, la Carta di Pisa https://docs.sip.it/pisa.pdf

47. La carta di Pisa http://www.simpios.eu/wp-content/uploads/2017/04/09-LaCarta-di-Pisa.pdf
Ready to submit your research? Choose BMC and benefit from:
- fast, convenient online submission
- thorough peer review by experienced researchers in your field
- rapid publication on acceptance
- support for research data, including large and complex data types
- gold Open Access which fosters wider collaboration and increased citations
- maximum visibility for your research: over $100 \mathrm{M}$ website views per year
At BMC, research is always in progress. 